\title{
Determinants of Stock Returns with Liquidity as Moderators: Empirical Study in Indonesia Stock Exchange
}

\author{
$1^{\text {st }}$ Aminullah Assagaf \\ Faculty of Economics and Business \\ Dr. Soetomo University \\ Surabaya, Indonesia \\ https://orcid.org/0000-0002-1719-2227
}

\author{
$2^{\text {nd }}$ Dwi Kartikasari \\ Dept. of Business and Management \\ Politeknik Negeri Batam \\ Batam, Indonesia \\ https://orcid.org/0000-0002-3222-4426
}

\begin{abstract}
This study aims to analyze the factors affecting stock returns in the Indonesia Stock Exchange, by selecting a sample of 20 companies listed on the LQ 45 in the last three years. This study found that the growth of profitability as a key determinant in this study exerted positive and significant effect on stock returns, while the accrual-based earnings management did not significantly determine stock returns. The authors used two control variables namely capital expenditure and firm size, the latter served very well as a control variable otherwise the results can be misleading. As a moderating variable, liquidity significantly moderated the relationship between profitability and stock returns, further, liquidity modulated the magnitude of the effect of profitability on stock returns. Liquidity as moderating variable increased the confidence level of the accrual-based earning management, however, the end result of significance level was still above the threshold, thus liquidity did not significantly moderate the relationship between accrualbased earnings management and stock returns. The variables in this study explains $\mathbf{2 8 , 4 \%}$ of the variation of the stock returns and the remaining $71,6 \%$ is explained by other variables outside of this study.
\end{abstract}

Keywords - stock returns, liquidity, profitability, moderators, control variables

\section{INTRODUCTION}

This study aims to analyze the phenomenon of uncertainty over the company's stock price in the Indonesia Stock Exchange or IDX characterized by fluctuations in the stock price index over the period 2018-2019. For example Jakarta Stock Index (JCI) in early March 2018 was 6.606; midNovember 2018 got down $11.3 \%$ to 5.858; and the beginning of March 2019 got up $11.0 \%$ to 6.500 .

JCI reflects the weighted average of stock returns of all companies listed on the Indonesia Stock Exchange. Companies are individually experiencing varying patterns, but generally following the trend of the index. Fluctuations of JCI can be exploited by investors by purchasing when the price is low and selling when the price is high. But generally speaking, investors are dominantly risk averse, hence, fluctuations are considered as risk rather than opportunity. To understand more deeply about the fluctuations of stock returns, it is necessary to know the key factors that significantly influence the rise and fall of stock prices in the Indonesia Stock Exchange.

References are abundant in this field, resulting in various but sometimes contradictory findings. This study uses profitability and accrual earnings management as hypothetically determinants of stock returns like previous studies [1,2].

This study is based on the agency theory and the signaling theory. It is associated with management actions to meet the interests of shareholders and present the information in the form of a signal to market participants that would affect stock prices and the impact on stock returns. In connection with the second theory, the study predicts that stock returns are influenced by the level of profitability, liquidity, and earnings management practices undertaken by the company.

The authors believe that this research is important to enrich literature in this area and provide a deeper understanding and confidence for investors of the Indonesian stock exchange. Specifically, this study examines: (a) whether the growth of profitability significantly affects stock returns, (b) whether the accrual-based earnings management significantly affects stock returns, (c) whether liquidity moderates the relationship between profitability and stock returns, and (d) whether liquidity moderates the relationship between accrual-based earnings management and stock returns on the Indonesian stock exchange, given that capital expenditure and firm size variables are hold constant as control variables.

\section{LITERATURE REVIEW}

Theoretical basis used in this study is the agency theory arguing that managers are to achieve the goals set by the shareholders, although each parties, either manager or shareholders have different interests, on one hand one is to maximize compensation/bonus, on the other hand one is to maximize earnings [3].

Another theory used is signaling theory. The company will give a signal through action and communication [3]. The 
company adopts the signal in revealing the hidden attributes of stakeholders. The company strives to provide information through the financial report, gives a signal about the various factors that affect the company's financial condition, and communicate the strategy and policy to improve financial performance.

Previous work found that profitability especially return on equity have a significant effect on stock returns [4], although another work found contradictory result [1]. Similar to the reference, this research hypothesizes as follows.

H1: Profitability has positive and significant effect on stock returns on the Indonesian stock exchange.

Earnings management significantly affects stock returns $[5,6]$. Similar to the reference, this research hypothesizes as follows.

H2: Accrual-based earnings management has positive and significant effect on stock returns on the Indonesian stock exchange.

Liquidity significantly affects stock returns [7]. But in this study, liquidity is used as a moderating variable by proposing hypotheses $\mathrm{H} 3$ and $\mathrm{H} 4$ below.

H3: Liquidity significantly moderates the relationship between profitability and stock returns

H4: Liquidity significantly moderates the relationship between accrual-based earnings management and stock returns.

Figure below shows the framework of determinants of stock returns in this paper.

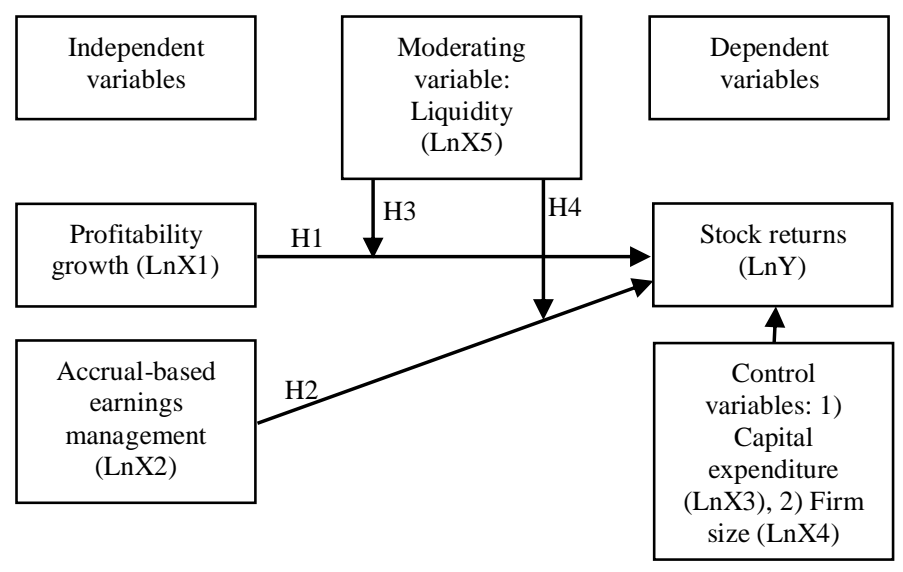

Figure 1: Framework of determinants of stock returns

To make the results more comprehensive, this study uses two control variables, namely capital expenditure and firm size. Both control variables are intended to better understand the other variables being tested. This study also uses liquidity as moderating variable to test whether liquidity temper or modulate the magnitude of the effect of profitability and earnings management on stock returns.

\section{METHODOLOGY}

The authors use purposive sampling method by determining samples as 20 shares most actively traded during the last 3 years, selected from LQ 45, thus the sample observations in the study are 60.

The authors use the following definitions to define variables:

\section{Stock returns $(\mathrm{Y})$}

Stock returns is a percentage of the difference between the current stock price $\mathrm{P}(\mathrm{t})$ and the previous stock price $\mathrm{P}(\mathrm{t}-1)$, divided by the previous stock price [8].

$$
\mathrm{Y}=(\mathrm{P}(\mathrm{t})-\mathrm{P}(\mathrm{t}-1)) /(\mathrm{P}(\mathrm{t}-1))
$$

\section{Profitability growth (X1)}

Growth in profitability is defined as the percentage of change between the return on equity (ROE) of current period (t) with a return on equity (ROE) of the previous period ( $t-1)$ [4].

$$
\mathrm{X} 1=(\mathrm{ROE}(\mathrm{t})-\mathrm{ROE}(\mathrm{t}-1)) /(\mathrm{ROE}(\mathrm{t}-1))
$$

3. Accrual-based earnings management (X2)

Accrual-based earnings management is management practices that affect the company's financial statements using accrual transactions [3].

$$
\mathrm{X} 2=(\Delta \mathrm{CA}-\Delta \mathrm{Cash})-(\Delta \mathrm{CL}-\Delta \mathrm{STD})-\text { Depreciation }
$$

Where: $\triangle \mathrm{CA}$ is a change in current assets; $\Delta \mathrm{CL}$ is a change in current liabilities; $\Delta$ Cash is a change in cash and equivalents; and $\triangle \mathrm{STD}$ is a change in short term debt that is included in current liabilities.

\section{Capital expenditure (X3)}

Capital expenditure is the amount of investment made by the company in a given period [9].

$$
\mathrm{X} 3=(\text { Fixed } \operatorname{assets}(\mathrm{t})-\text { Fixed } \operatorname{assets}(\mathrm{t}-1)) /(\text { Fixed assets }(\mathrm{t}-1))
$$

\section{Firm size $(\mathrm{X} 4)$}

Firm size is the value of assets used by the company as recorded in the financial statements at certain period [10].

$$
\mathrm{X} 4=\text { total assets }
$$

\section{Liquidity (X5)}

The company's liquidity is the company's ability to pay short-term debt [11].

$$
\mathrm{X} 5=(\text { Current asset }) /(\text { Current liabilities })
$$

The authors use nonlinear model to test the hypotheses of this study, arguing that the nonlinear analysis model has the ability to better explain the phenomenon. Based on the distribution of data, which can be tested through a scatter plot and determinand coefficient test, the result indicates that the nonlinear regression with adjusted R2 of 0,284 is more appropriate than the linear model with adjusted R2 of 0,132 . Nonlinear model used is based on Ln as noted below.

$\mathrm{LNY}=\beta 0+\beta 1 \operatorname{LnX} 1+\beta 2 \operatorname{LnX} 2+\beta 3 \operatorname{LnX} 3+\beta 4 \operatorname{LnX} 4+\beta 5$ $\operatorname{LnX} 5+\beta 6 \operatorname{LnX} 1 X 5+\beta 7 \operatorname{LnX} 2 X 5+\mathrm{e}$

Where: $\mathrm{LnY}=$ stock return, $\mathrm{LnX} 1$ = profitability growth, LnX2 = accrual-based earnings management, $\operatorname{LnX} 3=$ capital 
expenditure, $\operatorname{LnX} 4=$ firm size, $\operatorname{LnX} 5$ = liquidity, $\operatorname{LnX} 1 \mathrm{X} 5=$ interaction $\mathrm{X} 1$ and $\mathrm{X} 5$, and $\mathrm{LnX} 2 \mathrm{X} 5$ = interaction $\mathrm{X} 2$ and $\mathrm{X} 5$, $\beta 0=$ constant, $\beta 1 \ldots . . \beta 7=$ coefficient, $\mathrm{e}=$ error .

\section{RESULTS AND DISCUSSIONS}

\section{A. Descriptive statistics}

Descriptive statistics are shown in table below. Ln of stock returns has the average value of -3.280 spreading between the minimum value of -6.601 to maximum value of -928 , and standard deviation of 1.161 .

\section{TABLE I. DESCRIPTIVE STATISTICS}

\begin{tabular}{|c|l|r|r|r|r|}
\hline$\#$ & Variables & Mean & Std. Deviation & Min & Max \\
\hline 1 & LnY & -3.280 & 1.161 & -6.601 & -928 \\
\hline 2 & LnX1 & -1.654 & 1.200 & -5.263 & -153 \\
\hline 3 & LnX2 & 965 & 1.032 & -2.011 & 4.220 \\
\hline 4 & LnX3 & -2.168 & 1.162 & -6.822 & 917 \\
\hline 5 & LnX4 & 2.301 & 86 & 1.880 & 2.431 \\
\hline 6 & LnX5 & 691 & 675 & -798 & 1.944 \\
\hline 7 & LnX1X5 & -763 & 1.618 & -6.000 & 2.333 \\
\hline 8 & LnX2X5 & 2.151 & 1.174 & -189 & 6.235 \\
\hline
\end{tabular}

Where: $\mathrm{LnY}=$ stock return, LnX1 = profitability growth, LnX2 = accrual-based earnings management, LnX3 = capital expenditure, $\operatorname{LnX} 4=$ firm size, LnX5 = liquidity, LnX1X5 = interaction between $\mathrm{X} 1$ and $\mathrm{X} 5$, and $\mathrm{LnX} 2 \mathrm{X} 5$ = interaction between $\mathrm{X} 2$ and $\mathrm{X} 5$.

\section{B. Correlations}

The table below shows that correlations between stock returns variable and other variables are significant only for profitability variable (LnX1), capital expenditure control varibale ( $\mathrm{LnX} 4)$ and firm size control variable (LnX5). Correlations that are significant at the minimum level of 0,05 (2-tailed) are typed bold.

TABLE II. CORRELATIONS

\begin{tabular}{|r|c|r|r|r|r|r|r|r|r|}
\hline$\#$ & Variables & \multicolumn{1}{|c|}{ LnY } & LnX1 & LnX2 & LnX3 & LnX4 & LnX5 & LnX1 X5 & LnX2X5 \\
\hline 1 & LnY & 1 & & & & & & & \\
\hline 2 & LnX1 & $\mathbf{0 , 2 8 3}$ & 1 & & & & & & \\
\hline 3 & LnX2 & 0,213 & 0,029 & 1 & & & & & \\
\hline 4 & LnX3 & 0,007 & 0,060 & $-0,019$ & 1 & & & & \\
\hline 5 & LnX4 & $\mathbf{- 0 , 2 8 0}$ & $-0,197$ & $-0,031$ & $\mathbf{0 , 2 8 0}$ & 1 & & & \\
\hline 6 & LnX5 & $\mathbf{0 , 3 7 6}$ & 0,085 & 0,218 & $\mathbf{- 0 , 3 2 3}$ & $-0,067$ & 1 & & \\
\hline 7 & LnX1X5 & $\mathbf{0 , 2 8 5}$ & $-0,049$ & 0,050 & 0,108 & $\mathbf{- 0 , 2 5 8}$ & $-0,025$ & 1 & \\
\hline 8 & LnX2X5 & $-0,016$ & $-0,064$ & $-0,123$ & $-0,150$ & $\mathbf{- 0 , 3 3 7}$ & 0,081 & $\mathbf{0 , 3 1 8}$ & \\
\hline
\end{tabular}

\section{The classical assumption test}

The classical assumption test is required when using linear regression models through normality test, multicollinearity test, autocorrelation test and heteroskedacticity test. While the nonlinear regression model as used in this study does not require the classical assumption test.

\section{Hypotheses testing}

Table below shows that the variables that significantly influence the stock returns, namely: (a) the independent variable $\mathrm{X} 1$ of growth of profitability at significance level of 0,097 or $9,7 \%$, (b) the control variable of capital expenditure or $\mathrm{X} 4$ at significance level of 0,073 or $7,3 \%$, (c) the control variable of firm size or X5 at significance level of 0,002 or $0,2 \%$, and (d) interaction variables $\mathrm{X} 1$ and $\mathrm{X} 5$ at significance level of 0,025 or $2,5 \%$.

TABLE III. REGRESSION RESULTS

\begin{tabular}{|r|c|r|c|l|}
\hline$\#$ & Variables & Coefficient & Sig. & \multicolumn{1}{|c|}{ Remarks } \\
\hline 1 & LnY & $4.602,061$ & 0,266 & Not significant \\
\hline 2 & LnX1 & 0,189 & 0,097 & Significant at the 0,1 level (2-tailed) \\
\hline 3 & LnX2 & 0,092 & 0,481 & Not significant \\
\hline 4 & LnX3 & 0,132 & 0,297 & Not significant \\
\hline 5 & LnX4 & $-3,176$ & 0,073 & Significant at the 0,1 level (2-tailed) \\
\hline 6 & LnX5 & 0,670 & 0,002 & Significant at the 0,01 level (2-tailed) \\
\hline 7 & LnX1X5 & 0,201 & 0,025 & Significant at the 0,05 level (2-tailed) \\
\hline 8 & LnX2X5 & $-0,172$ & 0,168 & Not significant \\
\hline
\end{tabular}

Variable controls are not tested in hypotheses, thus this article confirms hypothesis $\mathrm{H} 1$ and $\mathrm{H} 3$ in addition to rejecting hypothesis $\mathrm{H} 2$ and $\mathrm{H} 4$. The above table also indicates that each one unit increment of X1, stock returns will increase 0,189 units. The regression model of determinants of stock returns is expressed as follows.

$\operatorname{LnY}=4.602,061+0,189 \operatorname{LnX} 1+0,092 \operatorname{LnX} 2+0,132 \operatorname{LnX} 3-$ 3,176 LnX4 + 0,670 LnX5 + 0,201 LnX1X5 - 0,172 LnX2X5

The adjusted coefficient of determination (R2) indicates the value of 0,284 which means that $28.4 \%$ of the variation of the stock returns is explained by the input variables in this study, and the remaining $71,6 \%$ is explained by other variables outside of this study. While F-test shows the value of the Fstatistics of 4,344 at significance level of 0,001 , which means that independent variables simultaneously and significantly determine stock returns.

\section{E. Discussions}

This paper finds that the growth of profitability (X1) strongly drives stock returns. The growth of profitability has been always a major concern of investors in making decisions, thus impacting on stock prices and stock returns. When a company wish to appeal for investors, it should pay more attention on its growth of profitability because the latter is considered as a key determinant.

The independent variable of accrual-based earnings management does not have a significant effect because the information system or the disclosure of financial reports easily accessible to investors, so the practice of accrual-based earnings management is not significant influence on stock prices and stock returns.

The coefficient of determination of 0,284 is relatively low. It means that stock returns are influenced by other factors than the key factors used in this study. Investors might simply tend to pay more attention to short-term fluctuations of the stock price disregarding fundamental analysis.

The control variable of capital expenditure (X3) does not significantly affect stock returns because this variable does not immediately impact on financial performance, but lag certain period to generate returns. While other control variable of firm size (X4) significantly affects stock returns, because companies that have a relatively large assets tend to have the ability to increase efficiency, improve services, and adopt latest 
technologies that enable them to win the competition. The authors argue that firm size has functioned very well as a control variable, and if this variable is not used as a control variable, it could potentially lead to bias and the results of this study can be misleading.

When liquidity plays as independent variable, it significantly affects stock returns because it plays an important role in the continuity and stability of working capital and the trust of third parties or business partners thus impacting on stock returns. As moderating variable, liquidity significantly moderates the relationship between profitability and stock returns. Further, liquidity modulates the magnitude of the effect of profitability on stock returns as can be seen from Table 3 where the significance level was 0,097 but once liquidity came in play the significance level was down to 0,025 and confidence level was up as a result. The same pattern where liquidity as moderating variable increases the confidence level also happens for the accrual-based earning management, however, the end result of significance level is still above the threshold, thus earning management practices is considered ineffective in increasing stock prices and stock returns.

\section{CONCLUSIONS}

The authors conclude that: (a) the independent variable of growth of profitability significantly affects stock returns as a key determinant in this study, (b) the independent variable of accrual-based earnings management does not significantly affect stock returns thus earnings management practices does not effectively improve stock prices and stock returns in the capital market, (c) as moderating variable, liquidity significantly moderates the relationship between profitability and stock returns, further, liquidity modulates the magnitude of the effect of profitability on stock returns, (d) liquidity as moderating variable increases the confidence level of the accrual-based earning management, however, the end result of significance level is still above the threshold, thus liquidity does not significantly moderate the relationship between accrual-based earnings management and stock returns, and (e) the variables in this study explains $28,4 \%$ of the variation of the stock returns and the remaining $71,6 \%$ is explained by other variables outside of this study.

\section{REFERENCES}

[1] Arista, D. (2012). Analisis Faktor - Faktor Yang Mempengaruhi Return Saham (Kasus Pada Perusahaan Manufaktur Yang Go Public Di BEI Periode Tahun 2005 - 2009). Jurnal Ilmu Manajemen dan Akuntansi Terapan, Vol. 3 (1), pp. 1-15.

[2] Kristiana, V.A., Sriwidodo, U. (2012). Analisis Faktor-Faktor yang Mempengaruhi Return Saham Investor pada Perusahaan Manufaktur di Bursa Efek Indonesia. Jurnal Ekonomi dan Kewirausahaan, Bol. 12 (1), pp. 1-11.

[3] Assagaf, A., Etty, M., Sekar, M., , Juniati, G. (2019). Estimates Model of Factors Affecting Financial Distress: Evidence from Indonesian State-owned Enterprises. Asian Journal of Economics, Business and Accounting, Vol. 11 (3), pp. 1-19.

[4] Carlo, M. A. (2014). Pengaruh Return On Equity, Dividend Payout Ratio, dan Price to Earnings Ratio Pada Return Saham. Jurnal Akuntansi Universitas Udayana, Vol. 1 (7), pp.150-164.

[5] Ambarwati, S.D.A. (2017). Pengujian Week-Four, Monday, Friday Dan Earnings Management Effect Terhadap Return Saham. Jurnal Keuangan Dan Perbankan, Vol. 13 (1), Pp. 1-14.

[6] Muid, D. (2007). Pengaruh Manajemen Laba Terhadap Kinerja Operasi, Return Saham Pada Perusahaan Publik Di Bursa Efek Jakarta (BEJ). Jurnal Dinamika Ekonomi \& Bisnis. Vol. 4 (2), Pp. 175-198.

[7] Sutriani, A. (2014). Pengaruh Profitabilitas, Leverage, Dan Likuiditas Terhadap Return Saham Dengan Nilai Tukar Sebagai Variabel Moderasi Pada Saham Lq-45. Journal Of Business And Banking, Vol. 4 (1), Pp. 67-80.

[8] Suharli, M. (2005). Studi Empiris Terhadap Dua Faktor Yang Mempengaruhi Return Saham Pada Industri Food \& Beverages Di Bursa Efek Jakarta. Jurnal Akuntansi \& Keuangan, Vol. 7 (2), Pp. 99 116.

[9] Rakhimsyah, L.A. (2011). Pengaruh Keputusan Investasi, Keputusan Pendanaan, Kebijakan Dividen dan Tingkat Suku Bunga Terhadap Nilai Perusahaan. Jurnal Investasim, Vol. 7 (1), pp. 31-45.

[10] Sudarsono, B., Bambang, S. (2014). Faktor-Faktor Yang Mempengaruhi Return Saham Pada Perusahaan Property Dan Real Estate Yang Terdaftar Pada Bursa Efek Indonesia Tahun 2009 S/D 2014. Jurnal Bisnis Dan Ekonomi (Jbe), Vol. 23 (1), 30-51.

[11] Lestari, R., Rita, A., Abrar, O. (2016). Analisis Likuiditas, Leverage, Profitabilitas, Aktivitas, Ukuran Perusahaan Dan Penilaian Pasar Terhadap Return Saham (Pada Perusahaan Real Estate Dan Property Di BEI) Periode Tahun 2009-2014. Journal of Accounting, Vol. 2 (2), pp. 1-19. 